Jurnal Konstruksi Hukum | ISSN: XXXX | E-ISSN: XXXX Vol. 1, No. 2, Oktober 2020, Hal. 237-242| Available online at https://www.ejournal.warmadewa.ac.id/index.php/jukonhum DOI: https://doi.org/10.22225/jkh.1.2.2596.237-242

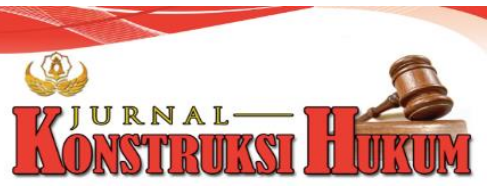

\title{
IMPLEMENTASI PERATURAN BUPATI NO. 58 TAHUN 2014 TERHADAP PENGELOLAAN ARSIP DI DINAS KEARSIPAN KABUPATEN BADUNG
}

\author{
Anak Agung Dinda Trisna Kesumadewi, Anak Agung Sagung Laksmi Dewi, Luh Putu \\ Suryani \\ Fakultas Hukum Universitas Warmadewa, Denpasar-Bali, Indonesia
}

\begin{abstract}
Archiving has an important role for the smooth running of an organization. Archiving serves as a source of information and monitoring tools that are needed by every organization in making reports, accountability, assessment and control as precisely as possible. The formulation of the problem in this study are: 1) How is the active and inactive dynamic archive arrangement process in the Archive Management Unit in Badung Regency Archives and Library Service in accordance with Badung Regent Regulation Number 58 of 2014? 2) What efforts are made by the Archives and Library Service Badung Regency so that every government agency in the Badung Regency Government implements the Badung Regent Regulation No. 58 of 2014 in the management of records? The technique of data collection is done through the method of recording. Data is then analyzed using systematic legal interpretation and legal arguments based on deductive logic. The conclusions of this study are: 1) the process of active and inactive dynamic archive arrangement in the Badung Regency Archives and Library Management Unit is to use classification codes and indexes. 2) Obstacles and Library Constraints in implementing Regent Regulation No. 58 of 2014 is that people's thoughts on filing are not well understood, facilities and infrastructure are still lacking, management staff at each SKPD do not understand about archival management, and Head of Service at each SKPD is less concerned with archive management personnel. The efforts of the Department of Archives in implementing Regent Regulation No. 58 of 2014 are by developing archival human resources, archiving socialization, archiving guidance, and community participation.
\end{abstract}

Keywords: Implementation; Regent Regulation No. 58 of 2014; Management of Archive

\section{PENDAHULUAN}

Arsip merupakan catatan rekaman dari suatu kegiatan atau dari segala sumber informasi dengan berbagai macam bentuk yang dibuat langsung oleh suatu lembaga, organisasi ataupun perorangan dalam rangka pelaksanaan suatu kegiatan. Arsip tidak hanya berupa dokumen-dokumen atau surat, akta, piagam, buku dan lainnya, namun juga dapat dijadikan sebagai bukti untuk suatu tindakan daalam keputusan (Fathurrahman, 2018). Perkembangan teknologi dan informasi menghasilkan arsip yang berbentuk digital berupa audio dan video. Mengingat jumlah arsip yang semakin banyak dibuat dan diterima oleh lembaga, organisasi, ataupun perorangan maka diperlukan manajemen pengelolaan arsip yang lebih baik. Pengelolaan arsip yang baik dikenal dengan sistem kearsipan melalui beberapa pekerjaan atau kegiatan untuk mengelola arsip yang ada. Arsip dinamis adalah arsip yang masih diperlukan secara langsung dalam perencanaan, pelaksanaan, dan penyelenggaraan kehidupan kebangsaan pada umumnya atau arsip yang digunakan secara langsung dalam penyelenggaraan administrasi Negara (Basir, 2016). Kearsipan merupakan pengelolaan catatan dari rekaman suatu kegiatan atau bersumber dari informasi yang mempunyai nilai kegunaan yang baik dan terencana baik itu arsip yang dibuat sendiri ataupun yang diterima, dengan tujuan untuk memudahkan ditemukan kembali apabila suatu saat diperlukan. Sistem kearsipan yang dilakukan secara optimal akan bisa melancarkan kegiatan dan tujuan dari suatu lembaga, organisasi, ataupun orang perorangan (Anggrawati, 2004).

Pentingnya arsip menyebabkan pengolahan ataupun manajemen arsip yang baik merupakan suatu kegiatan dalam upaya untuk menyimpan atau melestarikan arsip sebagai bukti sah dari sebuah instansi. Dengan adanya pengolahan yang baik, maka sebuah instansi tidak akan mengalami kerugian yang besar 
apabila sewaktu-waktu terjadi hal yang tidak diinginkan (Rusmiatiningsih, 2017). Lembaga arsip yang ada di daerah Badung yaitu Kantor Dinas Kearsipan dan Perpustakaan Kabupaten Badung. Arsip daerah di Kabupaten Badung yang dimaksud adalah pada Dinas Kearsipan dan Perpustakaan Kabupaten Badung. Setiap perangkat daerah memiliki kewajiban untuk mengelola arsipnya masing-masing selama arsip tersebut masih dalam kurun waktu di bawah 10 tahun. Apabila arsip tersebut telah berada dalam kurun waktu diatas 10 tahun maka tanggung jawab terhadap pengelolaan arsip dilimpahkan kepada Dinas Kearsipan dan Perpustakaan. Sistem pengarsipan adalah cara pengaturan atau penyimpanan arsip secara logis dan sistematis dengan memakai abjad, numerik / nomor, huruf ataupun kombinasi huruf dan nomor sebagai identitas arsip yang terkait (Rustamin \& Dewi, 2016).

Ada beberapa penelitia terdahulu yang relevan dengan penelitian ini, penelitian tentang Legalisasi arsip elektronik sebagai alat bukti hukum, penelitianya mengungkap bahwa Posisi arsip elektronik adalah memiliki legalitas yang sah sebagai alat bukti hukum dalam kasus persidangan (Rusmiatiningsih, 2017). Penelitian tahun 2019, mengungkap bahwa kendala pengarsipan juga terjadi dalam manajemen pengelolaan arsip yang masih belum maksimal dalam hal penyimpanan arsip dengan sarana dan prasarana yang belum memadai serta pemeliharaan arsip yang dilakukan oleh tiap-tiap organisasi belum sesuai dengan standar karena belum memiliki SOP yang berlaku dalam merawat maupun memelihara arsip yang disimpan mereka (Hidayat, 2018).

Penlitian ini bertujuan untuk mengetahui proses penataan arsip dinamis aktif dan inaktif di unit pengelolaan arsip di Dinas Kearsipan dan Perpustakaan Kabupaten Badung sesuai dengan Peraturan Bupati Badung Nomor 58 tahun 2014 dan mengetahui upaya yang dilakukan oleh Dinas Kearsipan dan Perpustakaan Kabupaten Badung agar setiap instansi pemerintahan di lingkungan Pemerintah Kabupaten Badung mengimplementasikan Peraturan Bupati Badung Nomor 58 tahun 2014 dalam pengelolaan arsip.

\section{METODE PENELITIAN}

Penelitian yang digunakan dalam penelitian ini adalah penelitian hukum normatif. Penelitian ini dilakukan dengan penedekatan studi kepustakaan terhadap bahan-bahan hukum primer dan sekunder yang terkait dengan permasalahan yang dibahas. Teknik pengumpulan dilakukan melelui metode pencatatan yaitu mengutip pasal-pasal yang ada dalam Peraturan Bupati Nomor 58 Tahun 2014 tentang tata kearsipan pemerintah Kabupaten Badung. Apabila semua bahan hukum yang diperlukan sudah lengkap, maka bahan hukum itu akan diolah dan dianalisa dengan menggunakan teknik interpretasi hukum secara sistematis dan argumentasi hukum berdasarkan logika deduktif. Penyajian dilakukan secara deskriptif analisis yaitu suatu cara analisis bahan hukum yang dilakukan dengan jalan menyusun secara sistematis kemudian diuraikan dengan apa adanya

\section{HASIL DAN PEMBAHASAN}

\section{Proses Penataan Arsip Dinamis Aktif dan Inaktif di Unit Pengelolaan Arsip}

Untuk mewujudkan penyelenggaraan kearsipan nasional yang komprehensif dan terpadu, lembaga kearsipan nasional perlu membangun suatu Sistem Kearsipan Nasional (Museliza, 2018). Kendala dalam pengelolaan arsip dinamis menjadikan sesuatu pekerjaan yang ada pada kearsipan menjadi terhambat. Adapun beberapa hambatan yang sering terjadi disetiap lembaga pemerintah dalam melakukan pengarsipan yaitu:

1. Kurangnya pengetahuan mengenai pentingnya arsip. Kurangnya pemahaman arti terhadap pentingnya arsip, mengakibatkan berfungsinya arsip sebagai pusat ingatan organisasi tidak tercapai, dan akhirnya tugas-tugas di bidang kearsipan dipandang rendah.

2. Tidak terpenuhinya persyaratan pegawai. Hal ini terbukti dengan adanya penempatan pegawai yang diserahi tugas tanggung jawab mengelola arsip tidak didasarkan pada persyaratan yang diperlukan, bahkan banyak yang beranggapan cukup dipenuhi pegawai yang berpendidikan rendah.

3. Kurangnya tempat penyimpanan dan peralatan kearsipan karena terlalu cepat bertambahnya volume arsip-arsip.

4. Tidak adanya pengaturan yang lebih detail mengenai kearsipan yang akan digunakan secara baku di suatu kantor/organisasi, sehingga masing-masing petugas melaksanakan pekerjaannya tidak ada keseragaman dan tidak ada tujuan yang jelas. 
5. Tidak ada peraturan yang jelas mengenai peminjaman arsip-arsip dari kantor atau lembaga-lembaga sehingga tidak ada budaya cara meminjam arsip yang benar.

6. Pegawai yang meminjam dan menggunakan arsip kantor atau lembaga sangat sering meminjam terlalu lama, sehingga besar potensi arsip itu tidak kembali lagi dan ketika dibutuhkan oleh yang membutuhkan maka arsip itu tidak ada.

7. Banyak arsip kantor yang tidak ditemukan atau hilang karena banyaknya yang meminjam dan menggunkannya tidak berdasarkan atas peraturan yang ada. Hal tersebut terjadi karena kurangnya kemajuan dari sistem atau petugasnya yang tidak teliti.

8. Tidak adanya rencana untuk penyusutan arsip-arsip yang sudah sangat lama sehingga terlalu banyak arsip lama yang menumpuk, bercampur dengan arsip-arsip yang tidak satu bidang sehingga arsiparsip itu susah untuk ditampung semuanya.

9. Kurangnya suatu pengawasan terhadap arsip-arsip yang diterima dan dikirim oleh satu unit tertentu. Hal tersebut disebabkan karena para pejabat dan pelaksana tidak memperdulikan fungsi unit pengawas termaksud.

Kendala-kendala yang dihadapi Dinas Kearsipan dalam mengimplementasikan Peraturan Bupati Nomor 58 Tahun 2014 adalah:

1. Pemikiran orang-orang tentang kearsipan belum dipahami secara baik, arsip dipandang sebelah mata/dipandang kurang penting.

2. Sarana dan prasarana yang ada di beberapa SKPD yang masih kurang/ belum lengkap di dalam pengelolaan kearsipan.

3. Tenaga pengelolaan di setiap SKPD kurang memahami tentang pengelolaan kearsipan.

4. Kepala Dinas pada setiap SKPD kurang memperhatikan dan kurang memberikan reward (penghargaan) kepada tenaga pengelolaan arsip.

\section{Upaya yang Dilakukan oleh Dinas Kearsipan dalam implementasi Peraturan Pemerintahan}

Upaya yang dilakukan Dinas Kearsipan dan Perpustakaan dalam mengimplementasikan Peraturan Bupati No 58 Tahun 2014 antara lain (Suparjati \& Dkk., 2004).

1. Mengembangkan sumber daya manusia terhadap arsip

Untuk dapat mengelola suatu arsip yang baik dan benar di setiap Satuan Kerja Pemerintah Daerah

(SKPD), setiap Satuan Kerja Pemerintah Daerah (SKPD) berkewajiban untuk melakukan pengembangan terhadap kuantitas dan kualitas sumber daya manusia kearsipan serta berkewajiban untuk menjalankan manajemen dibidang arsip, sekaligus berkewajiban untuk memilih salah 1 (satu) Staf khusus sebagai staf yang benar-benar ahli dalam mengelola Kearsipan. Dalam mengembangkan sumber daya manusia terdapat beberapa pengembangan diantaranya yaitu:

a. Mengembangkan sumber daya manusia yang memang benar-benar memiliki kualitas yang baik dan berkopetensi dalam bidang kearsipan tersebut.

b. Ada beberapa upaya yang dapat dilakukan oleh lembaga kearsipan dalam mengembangkan dan membina sumber daya manusia yang berkompeten dibidangnya yaitu:

c. mengadakan arsipasi berkompeten;

d. mengembangkan profesionalitas serta kompetensi arsipasi dengan cara pengawasan terhadap pendidikannya, melalui penyelenggaraan-penyelenggaraan, pengaturan yang baik, serta melatih kearsipan dengan lebih mementingkan kualitas;

e. Pengaturan fungsi serta letak hukum dari arsiparis;

f. Menyediakan tunjangan serta menjamin kesehatan terhadap profesi untuk sumber daya kearsipan.

g. Pengaturan yang lebih baik tentang wewenang, posisi hukum, kualitas, pelatihan serta pendidikan khusus terhadap sumber sumber daya arsipasi melalui aturan-aturan dari pemerintah

2. Mensosialisasikan mengenai kearsipan

Pentingnya dilakukan suatu cara yang lebih berkualitas mengenai kearsipan dengan tahapantahapan dari lembaga kearsipan secara berkelanjutan agar dari pusat sampai dengan daerah.

a. Dalam mensosialisasikan mengenai kearsipan lembaga kearsipan perlu melakukannya secara perlahan agar masyarakat dapat memahami lebih dalam dan menyadari pentingnya arsip.

b. Sosialisasi kearsipan dapat dilakukan dengan cara mendidik, melatih, membimbing serta memberikan penyuluhan menggunakan media elektronik dan informasi. 
c. Sosialisasi kearsipan ditujukan kepada lembaga-lembaga negara, pemerintah di daerah,perusahaan, organisasi politik, lembaga pendidikan, organisasi kemasyarakatan, serta orang perorangan.

d. Menyediakan pelayanan informasi mengenai arsip, memberikan konsul mengenai arsip, serta membimbing pengelolaan arsip dari lembaga kearsipan di setiap daerah.

3. Pembinaan Kearsipan

Pembinaan dibidang Kearsipan dapat dilakukan secara bertahap dan berkelanjutan dari pusat sampai dengan di daerah;

a. Lembaga kearsipan di tingkat nasional melaksanakan pembinaan terhadap kearsipan yang ada ditingkat nasional kepada kearsipan dari pusat sampai dengan didaerah-daerah yang ada pada provinsi atau kabupaten.

b. Lembaga kearsipan pada tingkat provinsi melakukan pembinaan pada kearsipan yang ada pada provinsi sampai dengan yang ada didaerah.

c. Lembaga kearsipan pada tingkat kabupaten melakukan pembinaan terhadap kearsipan di tingkat kabupaten kepada kearsipan yang ada di kabupaten atau kota.

d. Lembaga kearsipan pada tingkat perguruan tinggi melakukan pembinaan pada kearsipan yang ada diperguruan tinggi dalam kesatuan kerjanya serta pada civitas akademianya.

1. Masyarakat berperan serta di dalamnya.

a. Dalam menyelenggarakan kearsipan masyarakat juga dapat berperan serta didalamnya melalui orang perorangan atau dengan organisasi-organisasi baik itu organisasi politik ataupun organisasi kemasyarakatan lainnya.

b. Masyarakat dapat ikut serta berperan mewujudkan kearsipan dengan mengelola, menyelamatkan, menggunakan, serta menyediakan sumber daya pendukung lainnya, atau menyelenggarakan pelatihan dan pendidikan kearsipan.

c. Masyarakat dapat diikut sertakan oleh lembaga kearsipan dalam melakukan pengawasan, perlindungan, dan penyelamatan, serta sosialisasi mengenai kearsipan.

d. Keikutsertaan masyarakat didalam pengelolaan kearsipan dilakukan melalui:

1) Untuk menjamin perlindungan terhadap hak keperdataan serta hak atas intelektual perlu dilakukan pengarsipan agar tidak memunculkan timbulnya keraguan terhadap hak dan kewajiban ;

2) Arsip-arsip dari orang perorangan, keluarga, organisasi-organisasi politik atau kemasyarakat masing-masing disimpan dan dilindungi berdasarkan standar dan ketentuan yang sudah di atur dalam Undang-undang terkait.

e. Masyarakat yang ikut berperan serta dalam menyelamatkan arsip-arsip. Menurut (Sukoco, 2012). menyelamatkan arsip dapat dilakukan dengan berbagai macam cara diantaranya yaitu:

1) Melaporkan arsip statis kepada lembaga kearsipan yang berwenang;

2) Apabila terjadi adanya penjualan, pemalsuan, perusakan,dan pengubahan arsip yang dilakukan oleh lembaga Negara tanpa adanya prosedur yang sesuai dengan Undang-undang yang mengatur maka laporkan kepada lembaga kearsipan ;

3) Melakukan perlindungan dan penyelamatan terhadap arsip-arsip serta tempat penyimpanannya apabila terjadi bencana-bencana seperti bencana alam ataupun bencana lainnya dengan melakukan koordinasi kepada lembaga yang berwenang.

4) Masyarakat atau orang perorangan yang berperan serta dalam menyerahkan arsip yang memiliki ktegori DPA maka dapat diberikan hadiah berupa penghargaan dari pemerintah.

5) Masyarakat yang berperan serta dalam menggunakan arsip dilakukan dengan cara membudayakan untuk mengunakan dan memanfaatkan arsip sesuai dengan prosedur yang sudah diatur dalam peraturan yang berlaku.

6) Masyarakat yang ikut berperan serta menyediakan sumber daya mendukung dapat dilakukan dengan:

7) Menyumbang dana yang akan digunakan untuk menyelenggarakan kearsipan;

8) Mengawasi penyelenggaraan kearsipan berdasarkan peraturan perundangan yang berlaku;

9) Menjadi relawan dalam mengelola serta menyelamatkan kearsipan sesuai dengan kompetensinya masing-masing. 
10) Mengadakan penyelenggaraan pelatihan dan pendidikan kearsipan berdasarkan ketentuan dari peraturan perundangan yang berlaku.

11) Organisasi-organisai politik ataupun kemasyarakatan, serta orang perorangan melakukan penyerahan arsip statis dari kegiatan yang telah diberikan dana dari anggaran negara kepada lembaga kearsipan berdasarkan atas ketentuan peraturan perundangan yang berlaku.

Sedangkan upaya-upaya yang dilakukan Dinas Kearsipan dalam mengimplementasikan Peraturan Bupati Nomor 58 Tahun 2014 adalah:

1. Dari Tim Pembina Kearsipan Kabupaten Badung mengajak para tenaga pengolah kearsipan setiap SKPD dan perangkat desa untuk merubah pola pikir tentang arsip.

2. Tim pembina kearsipan Kabupaten Badung memberikan penjelasan dan sekaligus membina tenaga pengelolaan kearsipan setiap SKPD dan perangkat desa tentang pengelolaan arsip yang baik dan benar sesuai dengan Peraturan Bupati Nomor 58 Tahun 2014.

3. Selalu melakukan sosialisasi dan pelatihan secara teknis terhadap tenaga pengolah kearsipan setiap SKPD dan perangkat desa di Kabupaten Badung.

4. Selalu melakukan pembinaan kepada seluruh SKPD dan perangkat desa di Kabupaten Badung

\section{SIMPULAN DAN SARAN}

\section{Kesimpulan}

Adapun kesimpukan penelitian ini sebagai berikut:

1. Proses penataan arsip dinamis aktif dan inaktif di Unit Pengelolaan Arsip dan Perpustakaan Kabupaten Badung adalah menggunakan kode Klasifikasi dan Indeks. Kode klasifikasi berupa huruf, angka, dan gabungan antara huruf dan angka. Sedangkan Indeks ialah sarana penemuan kembali arsip untuk mengidentifikasi arsip-arsip melalui tanda pengenal dan juga sebagai alat bantu dalam menyimpan arsip.

2. Kendala Dinas Kearsipan dan Perpustakaan dalam Mengimplementasikan Peraturan Bupati Nomor 58 Tahun 2014 adalah pemikiran orang-orang tentang kearsipan belum dipahami secara baik, sarana dan prasarana yang masih kurang, tenaga pengelolaan di setiap SKPD kurang memahami tentang pengelolaan kearsipan, dan Kepala Dinas pada setiap SKPD kurang memperhatikan tenaga pengelolaan arsip. Dengan adanya beberapa faktor tersebut Dinas Kearsipan memiliki upaya dalam mengimplementasikan Peraturan Bupati No 58 tahun 2014 tersebut dengan beberapa cara yaitu pengembangan sumber daya manusia kearsipan, sosialisasi kearsipan, pembinaan kearsipan, dan adanya peran serta masyarakat.

\section{Saran}

Berdasarkan hasil penelitian ini, ada beberpa yang disaranka peneliti yaitu

1. Dengan adanya Peraturan Bupati Nomor 58 Tahun 2014 ini diharapkan dapat meningkatkan efisiensi dan efektifitas dari sisi pengelolaan arsip dinamis dengan baik dan benar sesuai dengan Peraturan Bupati Nomor 58 Tahun 2014 Dinas Kearsipan dan Perpustakaan Kabupaten Badung

2. Demi menunjang kesempurnaan pelaksanaan pengelolaan arsip yang baik dan sesuai dengan Peraturan Bupati Nomor 58 Tahun 2014 Dinas Kearsipan dan Perpustakaan Kabupaten Badung diharapkan dapat meningkatkan sosialisasi dan memberikan pemahaman tentang cara pengelolaan arsip dan juga pemahaman tentang pentingnya arsip dalam kehidupan bermasyarakat, berbangsa dan bernegara

\section{DAFTAR PUSTAKA}

Anggrawati, D. (2004). Membuat dan Menjaga Sistem Kearsipan untuk Menjamin Integritas. Armico.

Basir, B. (2016). Manajemen Kearsipan. PT. Bumi Aksara.

Fathurrahman, M. (2018). Pentingnya Arsip Sebagai Sumber Informasi. JIPI (Jurnal Ilmu Perpustakaan Dan Informasi), 3(2), 215-225.

Hidayat, S. (2018). Model Pengembangan Pramuwisata Olahraga dalam Bisnis Pariwisata di Provinsi Bali. 5(1), $8-16$

Museliza, V. (2018). Analisis Pengelolaan Sistim Kearsipan Statis pada Dinas Perpustakaan dan Kearsipan Kota Pekanbaru. Jurnal El-Riyasah, 9(2), 15-38.

Rusmiatiningsih. (2017). Legalisasi Arsip Elektronik Sebagai Alat Bukti Hukum. Jurnal Kearsipan, 12(1), 101113. 
Jurnal Interpretasi Hukum

Vol. 1, No. 2, 2020

Rustamin, Z., \& Dewi, A. P. (2016). Sistem Pengarsipan Surat Masuk dan Surat Keluar Pada Kantor Sekretariat DPRD Provinsi Sulawesi Tenggara Menggunakan Borland Delphi 7. Sistem Informasi Dan Teknik Komputer, 1(2), 165-172.

Sukoco, B. M. (2012). Manajemen Administrasi Perkantoran Modern. Erlangga.

Suparjati, \& Dkk. (2004). Tata Usaha dan Kearsipan Seri. Kanisius. 